\title{
Host plants as reservoirs of the main oil-producing cabbage crops pests in the eastern forest-steppe of Ukraine
}

\author{
S.V. Stankevych ${ }^{10}$, M.D. Yevtushenko ${ }^{10}$, I.V. Zabrodina 1, I.P. Lezhenina ${ }^{1}$, H.V. Baidyk ${ }^{10}$, \\ M.O. Filatov 1, L.Ya. Sirous 1, D.D. Yushchuk 1, V.O. Melenti 1, N. V. Lutytska ${ }^{10}$, \\ Yu. O. Nakonechna 1 ${ }^{10}$, O.A. Molchanova ${ }^{1}$, A.V. Matsyura 2
}

${ }^{1}$ V.V. Dokuchaiev Kharkov National Agrarian University, v. Dokuchaevske, Kharkiv region, 62483, Ukraine

${ }^{2}$ Altai State University, Barnaul, Russian Federation

*Corresponding author E-mail: sergejstankevich1986@gmail.com

Received: 15.10.2020. Accepted 27.11.2020

\begin{abstract}
Such biotic factor as the vegetation distribution, which is the forage base for most insects, influences their spreading greatly. This connection is strongly expressed among the harmful herbivorous insects. The presence and distribution of the plants which are cultivated or used by humans and on which the insects are fed is certainly the first and basic condition for the emergence of a zone or a breeding ground of harmfulness. The presence of the most preferred by the insects fodder plants often leads to the formation of a zone or a center of the greatest damage (in the presence of other favorable conditions for the existence and reproduction of the pest). In the course of the researches concerning the identification of the host plants as reservoirs of the main oil producing cabbage crops pests which have been conducted in 2011-2014 in the communities (meadows, roadsides of highways and field perimeters) of the Kharkiv district of the Kharkiv region it has been found out the host plants as reservoirs for the dominant pests of the oil producing cabbage crops were dandelion, caustic buttercup, field mustard, hedge mustard, tansy mustard, yellow rocket and field shepherd's purse. The largest number of species of the host plants as reservoirs was found on the roadsides of highways and along the field perimeters ( 6 species) and on the meadows ( 2 species).The cruciferous fleas, rape blossom beetles and cruciferous bugs visited such crops as field mustard, hedge mustard and yellow rocket most often. Field shepherd's purse was the least significant among the identified host plants as reservoirs. Only a small amount of the cabbage fleas fed on this crop. This fact can be explained by the small white flowers that do not attract the rape blossom beetles and rose chafers as well as by a ground flat leaf rosette, which is always covered with dust and prevents the fleas and bugs from feeding.

Key words: oil producing cabbage crops, host plants as reservoirs, cruciferous fleas, cruciferous bugs, rape blossom beetle, rose chafer.
\end{abstract}

\section{Introduction}

The identification of conditions that contribute to the reproduction of the harmful insects in one place or another in many cases makes it possible to scientifically substantiate and implement the measures in order to limit their harmful activity and even completely eliminate the danger.

It is well known that the insects, both geographically and locally, are extremely unevenly distributed. This unevenness is caused by the differences in the natural and economic conditions of the particular regions, the differences on which both the possibility of existence and the intensity of the insect reproduction depend. Such biotic factor as the vegetation distribution, which is the forage base for most insects, influences their spreading greatly. This connection is strongly expressed among the harmful herbivorous insects (Dobrovolskyi, 1959).

To a greater extent this connection is inherent in the insects feeding on a single kind of food or monophagous pests as well as in the insects feeding on a limited variety of food or oligophagous pests (Kozhanchikov, 1955).

The presence and distribution of the plants which are cultivated or used by humans and on which the insects are fed is certainly the first and basic condition for the emergence of a zone or a breeding ground of harmfulness. The presence of the most preferred by the insects fodder plants often leads to the formation of a zone or a center of the greatest damage (in the presence of other favorable conditions for the existence and reproduction of the pest) (Dobrovolskyi, 1959).

The monophagous pests that feed and reproduce on the crops which occupy a restricted area have the most sharply restricted zones or the breeding grounds with the greatest harmfulness. At the same time the ecological connections which are based on 
a high degree of physiological and ecological adaptation to the feeding on the certain plants and to the conditions of growth and agricultural techniques of cultivation of the insect nourishing crops are revealed (Kozhanchikov, 1955).

In the first turn the human economic activity leads to the change of the natural vegetation cover and replacement it by a few new species of plants and this fact is extremely strongly reflected in the quantitative and qualitative indices of the entomofauna (Buch, 1998, Wachowiak, 1999). The pure crops in nature do not occupy the large areas, but they can occupy 100 or more hectares in the agricultural ecosystems and much more heavily populated by the pests (Tachvanainen, Root, 1972).

As B.V. Dobrovolskyi (Dobrovolskyi, 1959) notes the first and the main condition for the emergence of the harmful zones of any kind of insects is the presence and distribution of their fodder crops (in the presence of other favourable conditions for their reproduction and spreading). Under natural conditions the insects feed on the wild growing plant species and weeds; this fact greatly regulates their number. Therefore the anthropic factor begins to play a significant role. In the first turn the human economic activity leads to the change of the natural vegetation cover and replacement it by a few new species of plants which is extremely strongly reflected in the quantitative and qualitative indices of the entomofauna. New relationships are formed between the species; the trophic chains are restructured and the adaptations to exist in a changed environment are arisen. Certain species of the pests also become dominant under favorable weather and biological conditions (Buch, 1998, Wachowiak, 1999).

A striking example of this is the pests of the cabbage crops. According to the data of M.M. Bogdanov-Katkov (Bogdanov-Katkov, 1920) the pests of the cabbage crops under natural conditions feed on the following plants: field shepherd's purse (Capsella bursa-pastoris Moench.), field pennycress (Thlaspi arvense L.), yellow rocket (Barbarea vulgaris R. Br.), field pepper weed (Cardaria campestre R. Br.), pepper grass (Cardaria draba L.), camelina (Camelina dentata Pers.), wild radish (Raphanus rapanistrum $\mathrm{L}$.) and others. Timely destruction of these weeds in all crop rotation fields limits the development of the pests.

The number of weeds in the natural biocoenosis is not significant and therefore the cultivated plants from the Brassicaceae family play the decisive trophic role for the insects; the acreage under these crops is constantly increasing. Their species and variety composition is very diverse. In 2018 according to the State Register of Plants Varieties Suitable for Distribution in Ukraine the following number of the cabbage crops varieties is indicated: white cabbage -242 varieties, cauliflower - 77 varieties, red cabbage - 33 varieties, Pe-tsai cabbage -27 varieties, broccoli cabbage -22 varieties, Savoy cabbage -10 varieties, turniprooted cabbage -9 varieties, Brussels sprouts -6 varieties, small radish -76 varieties, garden radish -10 varieties, perennial wall-rocket -3 varieties, turnips -2 varieties, green mustard -2 varieties, field mustard -2 varieties, rocket salad -1 variety, black radish -1 variety, field turnip - 1 variety, winter rape - 257 varieties and 114 parent components, spring rape -54 varieties and 16 parent components, spring leaf mustard - 11 varieties, white mustard -10 varieties, spring false flax -9 varieties, oily radish -5 varieties, winter leaf mustard -7 varieties, field mustard -3 varieties, annual turnip rape -2 varieties, black mustard -2 varieties, green mustard -2 varieties and colza -1 variety.

Today the main oil producing crops from the Brassicaceae family in the world and in Ukraine are winter rape (Brassica napus oleifera bienis D. C.) and spring rape (Brassica napus oleifera annua Metzg.). Currently the acreage of these crops in the world is over 40 million hectares, and in Ukraine there are more than 1 million hectares. Less common crops are white mustard (Sinapis alba L.) and Chinese mustard (Brassica juncea Gzem.). The world acreage under mustard is about 3,0 million hectares (in Ukraine there are about 100 thousand hectares). Other oil producing crops from the Brassicaceae family such as spring winter cress (Brassica campestris L.), winter rape (Brassica rapa oleifera DC), winter false flax (Camelina sativa subsp. pilosa N. Zinge), spring false flax (Camelina sativa var. Glabrata (DC.), oily radish (Raphanus sativus L. var. oleiformis Pers) and black mustard (Brassica nigra (L.) Koch) occupy only a small area, while the Abyssinian mustard (Crambe abyssinica Hosts. ex. RE Fr.) is not grown in our country at all. In addition the new fodder crops from the Brassicaceae family such as perko and cow cabbage that are new for our country, are being tested at the research stations.

It is impossible to obtain high and sustainable yields of all agricultural crops without protecting the plants from the harmful insects. The losses of the crops because of the pests are enormous, especially during their mass reproduction. The entomological community of the rape agricultural system consists of several hundred species. As a result of the vital activity of the insect pests up to $50 \%$ of the crops (and even more) can be lost, and the yield increase at the level of $25-55 \%$ can be ensured due to the activity of the insect pollinators (Pruszynski, 1995).

According to a number of the authors (Kryshtal, 1959; Vasyliev, 1989; Yevtushenko, Stankevych, Vilna, 2014; Yevtushenko, Vilna, Stankevych, 2017) the cruciferous bugs from the Eurydema genus, the cruciferous fleas from the Phyllotreta genus, the rape blossom beetle (Meligethes aeneus F) and the rose chafer (Epicometis (Tropinota) hirta Poda.) cause the annual significant losses of the oil producing cabbage crops in the Forest-Steppe zone of Ukraine.

In the studied literature we have found sometimes quite contradictory information as for the wild plants on which the pests of the oil cruciferous crops can feed. Even less data on this issue can be found regarding the Eastern Forest Steppe of Ukraine and the Kharkiv region in particular.

Therefore the purpose of our research was to identify the main host plants as reservoirs of the oil producing cabbage crops pests under the conditions of the Kharkiv district of the Kharkiv region as well as to identify the stations where such plants are concentrated in large quantities, which promotes the mass reproduction of the pests which then populate the agricultural system.

\section{Materials and methods}

The researches regarding the identification of the host plants as reservoirs of the main oil producing cabbage crops pests were carried out in 2011-2014 in Rogan, villages Mala Rogan, Elitne, Vilkhivka, Biskvitne and Koropy of the Kharkiv district of the Kharkiv region. The meadows (the valley of the Roganka river), the perimeters of the fields and the roadsides of highways where the species of the researched host plants as reservoirs of the main oil producing cabbage crops pests grew were chosen as the stations for conducting the researches. From each of the studied stations a section of about $1 \mathrm{~km}$ in length was chosen and in 
hundreds plants of one species were inspected and visually counted the detected pests, and then their density per plant was calculated.

\section{Results}

The cruciferous fleas on the farms of the Eastern Forest-Steppe of Ukraine appear in early spring (I-II decades of April). The beetles cause harm to all species of plants, but initially they feed mainly on different cabbage weeds. According to the literary data among the wild growing cabbage plants the beetles prefer Indian cress, hedge mustard, hoary alyssum, tansy mustard, pepper weed, sea kale, garlic mustard, erysimum, yellow rocket, wild radish, gillyflower, pennycress, etc. Undulating flea beetle and mesographe flea beetle feed on the leaves of field shepherd's purse and flea beetle feeds on the leaves of candytuft. When the sprouts of spring rape appear most beetles migrate to them and within 2-3 days completely destroy the sprouts during the reproduction on a mass scale. The beetles scrape the epidermis from the leaves and eat out the terminal bud. Hot and dry weather favours the increasing of the cruciferous fleas' harmfulness. On the one hand it is explained by the increased activity and voracity of the beetles connected with restoring the water balance of their bodies, and on the other hand it is explained by the fact that in dry weather the plants are more weakened and vulnerable to damage by the insects. The beetles cause damage beginning from the phase of sprouting and up to the crops harvesting. The larvae of the large striped flea beetle penetrate the leaf, mine it and stay there until turning into a pupa, and the larvae of the horseradish flea beetle develop inside the leaf stalk and in the medial vein of horseradish and cabbage leaves (Yevtushenko, Stankevych, Vilna, 2014).

One of the most dangerous pests of the cabbage crops in all areas of their cultivation is the rape blossom beetle (Meligethes aeneus F.); it can damage the plants in the budding and flowering phenophases. At first the beetles populate the flowers of dandelion, tall buttercup and yellow rocket and later they appear on the flowers of fruit trees (cherry-tree, apple-tree, etc.). Te beetles appear on the cultivated cabbage crops with the emergence of the first green buds. The beetles feed on the inner parts of the flowers (pistils, stamens, pollen and petals). The damaged buds turn yellow and fall down. Feeding mainly on the pollen of the opened flowers the rape blossom beetles are less harmful during the friendly and rapid flowering. However the mass appearance of the beetles can also cause the significant damage during the period of flowering (Yevtushenko et al., 2014).

The cruciferous bugs actively populate the crops of oil producing cabbage crops beginning from the stemming phase. According to the literary data among all wild growing plants the bugs prefer different types of hedge mustard. The damage is caused by the adult bugs and their larvae; they pierce the skin of the leaves or the flower-bearing shoots with the proboscis and suck the juice from them. The light spots appear at places of piercing, the tissue dies, falls out and the irregular holes are formed. When the seeds are damaged, the flowers and ovary fall down and the quality of the seeds deteriorates. The harmfulness of the bugs increases significantly in dry and hot weather (Yevtushenko et al., 2017).

The mustard bug (Eurydema ornata L.) damages the seeds of the cruciferous crops, especially cabbage, garden radish, black radish as well as the oil producing crops, namely mustard, false flax, rape, sea kale, etc. It is also closely associated with the wild growing cruciferous plants on which the bugs are often numerous (Puchkov, 1961).

The cabbage bug (Eurydema ventralis Kol.) damages almost all cabbage plants as well as the caper plants. It is dangerous for the cabbage seedlings and causes severe weakening or complete death of the plants (Puchkov, 1961).

Pentatomid rape bug (Eurydema oleracea L.) damages different varieties of cabbage, radish, Russian turnip, common turnip, horseradish, rape, false flax and sea kale; and during the period of the additional feeding it also damages sunflower, sugar beet transplants, ears of rye, wheat, barley, leaves of potato and other plants on which the larvae can develop (Puchkov, 1961).

Rose chafer (Epicometis hirta Poda.) is a dangerous pest of almost all agricultural crops in the budding and flowering phases. In recent years the pest has gained the economic importance not only for the fruit, but also for the field crops including the oil producing cabbage crops. The damage is caused by the beetles which gnaw out the flowers of fruit trees, rose, rose-bush, rowan tree, June berry, almond, lemon, tangerine, grapes (buds, ovaries and young leaves), horse chestnut, snowball-tree, lilac, privet, beetroot, elderberries, golden currant, black currant (young leaves and flowers), Elea gnus, peony, poppy, black radish, rocket salad, rape, mustard, cabbage (seeds), beet (transplants), common flax, rhubarb, cucumbers, watermelons, melons, pumpkin, ambary hemp, cotton, castor-oil plant, strawberries, holy clover, peas (leaves and sprouts), clover, vetch, beans, soybeans, haricot, alfalfa, gram chick-peas, sunflower, safflower, tomato, daisy, tulip, ears of rye, wheat, barley, panicles of millet, corn and other plants (Rozova, 2011; Chernii, 2011).

The population density of the main pest species of oil producing cabbage crops on the host plants as reservoirs at the researched stations in 2011-2014 is presented in Tables 1 and 2. The researches have shown that among all host plants as reservoirs dandelion (Taraxacum officinale Wigg.) and caustic buttercup (Ranunculus acris L.) are the first plants that appear in spring. These species of plants are the typical representatives of meadow vegetation. Dandelion is also spread along the highways and around the perimeters of the fields, but buttercup only occurs on the meadows under the conditions of high humidity. Their main role is to be the host plants as reservoirs for the insects that feed on the pollen of flowers; these insects are the rape blossom beetle and rose chafer. These plants begin to bloom in late March, but feeding of the cruciferous fleas has not been noted on them.

Other five plant species, namely field mustard (Sinapis arvensis L.), hedge mustard (Sisymbrium Loeselii L.), tansy mustard (Descurainia Sophia (L.), Webb. ex Prantl.), yellow rocket (Barbarea vulgaris R. Br.) and common shepherd's purse (Capsella bursa-pastoris Moench.) are the plants of the Brassicaceae family and serve as a forage base for the specialised cabbage pests and multi-faceted pests. They can be found at two other investigated stations: on the roadsides of highways and along the perimeters of the fields.

In early April, we have found the rape blossom beetle and rose chafer on the flowering plants of buttercup and dandelion. The imagoes of these pests' species feed on the pollen of flowers, stamens and pistils. Caustic butter cup only occurred on the 
meadows; its population density during the years of the researches ranged from 16 to 29 plants $/ \mathrm{m}^{2}$. On average, each plant had 0.2-0.4 specimens of the rape blossom beetle and rose chafer (Tables 1, 2).

Dandelion occurred at all three investigated stations. On the meadows its population density was $22-29$ plants $/ \mathrm{m}^{2}$, along the perimeters of the fields it was 14-18 plants $/ \mathrm{m}^{2}$, and on the roadsides of highways it was 13-18 plants $/ \mathrm{m}^{2}$. The population density of the rape blossom beetle ranged from 1.9 specimens/plant on the roadsides of highways to 3,6 specimens/plant on the meadows, and that of the rose chafer was 0.3-0.8 specimens/plant. This fact makes it possible to suggest that most rape blossom beetles hibernate in the ground litter in the areas close to the meadows (Tables 1, 2).

Table 1. Population density of main pests of oil producing cabbage crops on host plants as reservoirs at researched stations of Eastern Forest-Steppe of Ukraine in 2011-2012

\begin{tabular}{|c|c|c|c|c|c|c|c|c|c|c|c|}
\hline \multirow{3}{*}{\multicolumn{2}{|c|}{ Variant }} & \multicolumn{10}{|c|}{ Year of research } \\
\hline & & \multicolumn{5}{|c|}{2011} & \multicolumn{5}{|c|}{2012} \\
\hline & & \multirow{2}{*}{$\begin{array}{l}\text { population } \\
\text { density at } \\
\text { scation, } \\
\text { pieces } / \mathrm{m}^{2}\end{array}$} & \multicolumn{4}{|c|}{ pests population densigy, specimens/plant } & \multirow{2}{*}{$\begin{array}{c}\text { population } \\
\text { density at } \\
\text { station, } \\
\text { pieces/m2 }\end{array}$} & \multicolumn{4}{|c|}{ pests population density, specimens/olant } \\
\hline $\begin{array}{l}\text { plancs } \\
\text { species }\end{array}$ & stations & & $\begin{array}{c}\text { Phyllotreta } \\
\text { spp. }\end{array}$ & $\begin{array}{l}\text { Meligethes } \\
\text { aeneusf. }\end{array}$ & $\begin{array}{c}\text { Eurydema } \\
\text { spp }\end{array}$ & $\begin{array}{l}\text { Epicometis } \\
\text { Tropinota) } \\
\text { hirta Poda. }\end{array}$ & & $\begin{array}{c}\text { Phywotreta } \\
\text { spp. }\end{array}$ & $\begin{array}{l}\text { Meligecties } \\
\text { aeneus F. }\end{array}$ & $\begin{array}{c}\text { Eurydema } \\
\text { spp. }\end{array}$ & $\begin{array}{l}\text { Epicometis } \\
\text { Tropinotal } \\
\text { hirtaPoda. }\end{array}$ \\
\hline \multirow{3}{*}{$\begin{array}{c}\text { Taraxacum } \\
\text { officinale } \\
\text { Wigg. }\end{array}$} & meadows & 22 & 0 & 2.6 & 0 & 0.4 & 25 & 0 & 3.1 & 0 & 0.6 \\
\hline & $\begin{array}{l}\text { roadsides of } \\
\text { highways }\end{array}$ & 15 & 0 & 2.2 & $\mathbf{0}$ & 0.3 & 13 & 0 & 1.9 & 0 & 0.5 \\
\hline & $\begin{array}{c}\text { fields } \\
\text { perimeters }\end{array}$ & 16 & 0 & 2.3 & 0 & 0.3 & 18 & 0 & 2.8 & 0 & 0.6 \\
\hline \multirow{3}{*}{$\begin{array}{c}\text { Ranunculus } \\
\text { acrisL }\end{array}$} & meadovis & 29 & 0 & 0.2 & 0 & 0.3 & 24 & 0 & 0.4 & 0 & 0.4 \\
\hline & $\begin{array}{c}\text { roadsides of } \\
\text { highways }\end{array}$ & 0 & 0 & 0 & 0 & 0 & 0 & 0 & 0 & 0 & 0 \\
\hline & $\begin{array}{c}\text { fields } \\
\text { perimeters }\end{array}$ & 0 & 0 & 0 & 0 & 0 & 0 & 0 & 0 & 0 & 0 \\
\hline \multirow{3}{*}{$\begin{array}{c}\text { Sinapis } \\
\text { arversisL. }\end{array}$} & meadovis & 0 & 0 & 0 & 0 & 0 & 0 & 0 & 0 & 0 & 0 \\
\hline & $\begin{array}{l}\text { roadsides of } \\
\text { highways }\end{array}$ & 3 & 15.3 & 5.2 & 2.1 & 0.1 & 2 & 14.2 & 4.8 & 2.6 & 0.1 \\
\hline & $\begin{array}{c}\text { fields } \\
\text { perimeters }\end{array}$ & 4 & 18.5 & 5.4 & 2.0 & 0.1 & 2 & 20.1 & 5.1 & 2.3 & 0.1 \\
\hline \multirow{3}{*}{$\begin{array}{l}\text { Sisymbrium } \\
\text { LoeselifiL }\end{array}$} & meadov/s & 0 & 0 & 0 & 0 & 0 & 0 & 0 & 0 & 0 & 0 \\
\hline & \begin{tabular}{|c}
$\begin{array}{c}\text { roadsides of } \\
\text { highways }\end{array}$ \\
\end{tabular} & 4 & 14.2 & 4.1 & 2.4 & 0.1 & 4 & 13.8 & 3.4 & 1.7 & 0.1 \\
\hline & $\begin{array}{c}\text { fields } \\
\text { perimeters }\end{array}$ & 4 & 16.8 & 4.3 & 2.4 & 0.1 & 3 & 19.9 & 3.7 & 2.1 & 0.1 \\
\hline \multirow{3}{*}{$\begin{array}{c}\text { Descurainia } \\
\text { Sophia (L) } \\
\text { Webb. ex } \\
\text { Prantl. }\end{array}$} & meadovis & 0 & 0 & 0 & 0 & 0 & 0 & 0 & 0 & 0 & 0 \\
\hline & $\begin{array}{c}\text { roadsides of } \\
\text { highways }\end{array}$ & 3 & 7.6 & 1.6 & 1.4 & 0.1 & 4 & 5.4 & 1.1 & 1.8 & 0.1 \\
\hline & $\begin{array}{c}\text { fields } \\
\text { perimeters }\end{array}$ & 3 & 7.8 & 1.5 & 1.4 & 0.1 & 3 & 6.3 & 1.3 & 2.6 & 0.1 \\
\hline \multirow{3}{*}{$\begin{array}{c}\text { Barbarea } \\
\text { niganis } \\
\text { R.Br. }\end{array}$} & meadovis & 0 & 0 & 0 & 0 & 0 & 0 & 0 & 0 & 0 & 0 \\
\hline & $\begin{array}{c}\begin{array}{c}\text { roadsides of } \\
\text { highways }\end{array} \\
\end{array}$ & 6 & 17.1 & 6.1 & 1.8 & 0.2 & 5 & 17.4 & 9.1 & 2.8 & 0.1 \\
\hline & $\begin{array}{c}\text { fields } \\
\text { perimeters }\end{array}$ & 7 & 19.4 & 5.3 & 1.9 & 0.2 & 8 & 23.2 & 12.3 & 3.2 & 0.2 \\
\hline \multirow{3}{*}{$\begin{array}{l}\text { Capsella } \\
\text { bursa- } \\
\text { Aastoris } \\
\text { Medic. }\end{array}$} & meadovis & 0 & 0 & 0 & 0 & 0 & 0 & 0 & 0 & 0 & 0 \\
\hline & $\begin{array}{l}\text { roadsides of } \\
\text { highways }\end{array}$ & 18 & 0.2 & 0 & 0 & 0 & 15 & 0.1 & 0 & 0 & 0 \\
\hline & $\begin{array}{c}\text { fields } \\
\text { perimeters }\end{array}$ & 17 & 0.4 & 0 & 0 & 0 & 13 & 0.6 & 0 & 0 & 0 \\
\hline
\end{tabular}

Field mustard grows on the roadsides of highways (2-3 plants $\left./ \mathrm{m}^{2}\right)$ and along the perimeters of the fields $\left(2-4\right.$ plants $\left./ \mathrm{m}^{2}\right)$. It was populated by all the investigated pest species. The population density of the cruciferous fleas on this weed species ranged from 10.7 to 20.1 specimens/plant. With the beginning of budding the rape blossom beetles and the cruciferous bugs began to populate the plants. The population density of the rape blossom beetle reached 3.1-5.4 specimens/plant, and that of the bugs was 2.1-2.6 specimens/plant (Tables 1, 2). In the flowering phase the population density of the rose chafer was about $0.1-0.4$ specimens/plant.

Hedge mustard is found on the roadsides of highways and along the perimeters of the fields. Its average population density is about 3-6 plants $/ \mathrm{m}^{2}$. All the investigated species of pests were noted on this plant. The population density of the cruciferous fleas ranged from 9.2 to 19.9 specimens/plant. The rape blossom beetles and the cruciferous bugs began to populate the plants at the beginning of the budding phase. The population density of the rape blossom beetle ranged from 1.7 to 4.3 specimens/plant, and that of the bugs was 1.7-2.5 specimens/plant. During the flowering phase the population density of the rose chafer was within the limits of 0.1-0.2 specimens/plant (Tables 1, 2).

Tansy mustard is found on the roadsides of highways and the outskirts of the fields. At the given stations the population density of this species of weed was 3-4 plants $/ \mathrm{m}^{2}$. Due to its small leaves and smaller size of the flowers tansy mustard is less populated by the cruciferous fleas, rape blossom beetle and rose chafer. The average population density of the cruciferous fleas was 4.47.8 specimens/plant. At the beginning of the budding phase the plants are populated by the rape blossom beetles and cruciferous bugs. The population density of the rape blossom beetle ranged from 0.7 to 2.6 specimens/plant and that of the bugs was 1.3-2.6 specimens/plant. The population density of the rose chafer in the phase of flowering was no more than 0.1 specimens/plant (Tables 1, 2) 
Table 2. Population density of main pests of oil producing cabbage crops on host plants as reservoirs at researched stations of Eastern Forest-Steppe of Ukraine in 2013-2014

\begin{tabular}{|c|c|c|c|c|c|c|c|c|c|c|c|}
\hline \multirow{3}{*}{\multicolumn{2}{|c|}{ Variant }} & \multicolumn{10}{|c|}{ Year of research } \\
\hline & & \multirow[b]{3}{*}{$\begin{array}{l}\text { population } \\
\text { density at } \\
\text { station, } \\
\text { pieces/m² }\end{array}$} & \multicolumn{4}{|c|}{2013} & \multirow[b]{3}{*}{$\begin{array}{c}\text { population } \\
\text { density at } \\
\text { station, } \\
\text { pieces } / \mathrm{m}^{2}\end{array}$} & \multicolumn{4}{|c|}{2014} \\
\hline & & & pestsp & pulation den & ity, soecime & Is/plant & & pests $\mathrm{p}$ & pulation den & sity, specime & Is/plant \\
\hline $\begin{array}{l}\text { plants } \\
\text { species }\end{array}$ & stations & & $\begin{array}{c}\text { Phyinotreta } \\
\text { spop. }\end{array}$ & $\begin{array}{l}\text { Meligethes } \\
\text { genews } \mathrm{F} \text {. }\end{array}$ & $\begin{array}{c}\text { Eurydema } \\
\text { spp. }\end{array}$ & $\begin{array}{l}\text { Epicometis } \\
\text { Tropinota) } \\
\text { hirta Poda. }\end{array}$ & & $\begin{array}{c}\text { Phyllotreta } \\
\text { spp. }\end{array}$ & $\begin{array}{l}\text { Meligethes } \\
\text { denewsF. }\end{array}$ & $\begin{array}{c}\text { Euryderna } \\
\text { spp. }\end{array}$ & $\begin{array}{l}\text { Epicometis } \\
\text { Tropinota) } \\
\text { hirta Poda. }\end{array}$ \\
\hline \multirow{3}{*}{$\begin{array}{c}\text { Taraxacum } \\
\text { officinale } \\
\text { Wigz. }\end{array}$} & meadouss & 28 & 0 & 2.9 & 0 & 0.6 & 29 & 0 & 3.6 & 0 & 0.8 \\
\hline & $\begin{array}{c}\text { roadsides of } \\
\text { highways }\end{array}$ & 18 & 0 & 2.3 & 0 & 0.5 & 15 & 0 & 2.8 & 0 & 0.6 \\
\hline & $\begin{array}{c}\text { fields } \\
\text { perimeters }\end{array}$ & 14 & 0 & 2.6 & 0 & 0.4 & 17 & 0 & 3.1 & 0 & 0.8 \\
\hline \multirow{3}{*}{$\begin{array}{c}\text { Ranuncuius } \\
\text { acrisL }\end{array}$} & meadous & 16 & 0 & 0.3 & 0 & 0.4 & 18 & 0 & 0.2 & 0 & 0.3 \\
\hline & $\begin{array}{c}\text { roadsides of } \\
\text { highways }\end{array}$ & 0 & 0 & 0 & 0 & 0 & 0 & 0 & 0 & 0 & 0 \\
\hline & $\begin{array}{c}\text { fieids } \\
\text { perimeters }\end{array}$ & 0 & 0 & 0 & 0 & 0 & 0 & 0 & 0 & 0 & 0 \\
\hline \multirow{3}{*}{$\begin{array}{c}\text { Sinapis } \\
\text { arversisl. }\end{array}$} & \begin{tabular}{|l} 
meadours \\
\end{tabular} & 0 & 0 & 0 & 0 & 0 & 0 & 0 & 0 & 0 & 0 \\
\hline & $\begin{array}{c}\text { roadsides of } \\
\text { highways }\end{array}$ & 2 & 121 & 3.3 & 2.1 & 0.3 & 3 & 10.7 & 3.1 & 2.2 & 0.3 \\
\hline & \begin{tabular}{|c|} 
fieids \\
perimeters
\end{tabular} & 3 & 13.3 & 3.7 & 2.2 & 0.3 & 2 & 125 & 3.3 & 2.4 & 0.4 \\
\hline \multirow{3}{*}{$\begin{array}{l}\text { Sismbrium } \\
\text { Loeselít }\end{array}$} & meadours & 0 & 0 & 0 & 0 & 0 & 0 & 0 & 0 & 0 & 0 \\
\hline & \begin{tabular}{|c} 
roadsides of \\
highways
\end{tabular} & 5 & 10.4 & 2.2 & 2.3 & 0.1 & 6 & 9.2 & 1.7 & 2.1 & 0.2 \\
\hline & \begin{tabular}{|c|} 
fieids \\
perimeters
\end{tabular} & 6 & 11.7 & 2.6 & 2.5 & 0.2 & 6 & 9.8 & 1.9 & 2.2 & 0.2 \\
\hline \multirow{3}{*}{$\begin{array}{c}\text { Descurainia } \\
\text { Sophia(L) } \\
\text { Webb. ex } \\
\text { Prantl. }\end{array}$} & meadours & 0 & 0 & 0 & 0 & 0 & 0 & 0 & 0 & 0 & 0 \\
\hline & $\begin{array}{l}\text { roadsides of } \\
\text { highways }\end{array}$ & 3 & 5.6 & 0.9 & 1.6 & 0.1 & 3 & 4.4 & 0.7 & 1.3 & 0.1 \\
\hline & $\begin{array}{c}\text { fields } \\
\text { perimeters }\end{array}$ & 4 & 5.8 & 1.2 & 1.7 & 0.1 & 3 & 4.9 & 1.0 & 1.4 & 0.1 \\
\hline \multirow{3}{*}{$\begin{array}{c}\text { Barbarea } \\
\text { wigaris } \\
\text { R.Br. }\end{array}$} & meadous & 0 & 0 & 0 & & 0 & 0 & 0 & 0 & 0 & 0 \\
\hline & $\begin{array}{c}\text { roadsides of } \\
\text { highways }\end{array}$ & 6 & 15.3 & 4.2 & 1.6 & 0.4 & 6 & 13.1 & 3.3 & 1.7 & 0.5 \\
\hline & \begin{tabular}{|c|} 
fieids \\
perimeters
\end{tabular} & 7 & 17.1 & 3.1 & 1.9 & 0.4 & 10 & 183 & 4.6 & 1.8 & 0.6 \\
\hline \multirow{3}{*}{$\begin{array}{l}\text { Capsella } \\
\text { bursa- } \\
\text { austoris } \\
\text { Medic. }\end{array}$} & meadouss & 0 & 0 & 0 & 0 & 0 & 0 & 0 & 0 & 0 & 0 \\
\hline & $\begin{array}{c}\text { roadsides of } \\
\text { highways }\end{array}$ & 12 & 0.1 & 0 & 0 & 0 & 16 & 0.1 & 0 & 0 & 0 \\
\hline & $\begin{array}{c}\text { fieids } \\
\text { perimeters }\end{array}$ & 15 & 0.2 & 0 & 0.1 & 0 & 14 & 0.3 & 0 & 0.1 & 0 \\
\hline
\end{tabular}

Yellow rocket is one of the most common weeds from the Brassicaceae family. Along the highways and the perimeters of the fields we have noted the density population of yellow rocket at the level of 5-10 plants $/ \mathrm{m}^{2}$. The highest population density of the cruciferous fleas was noted on yellow rocket; it was from 13.1 to 23.2 specimens/plant. The rape blossom beetle populated yellow rocket most often in comparison with all the investigated weeds. Its population density ranged from 3.1 to 12.3 beetles per plant, and the population density of the bugs reached 1.6-3.2 specimens/plant. In the flowering phase the rose chafer also feeds on yellow rocket; its population density was 0.1-0.5 specimens/plant (Tables 1, 2).

Common shepherd's purse was found on the roadsides of highways and along the perimeters of the fields with a population density of 12-18 plants/m², which is 3.0-3.5 times higher in comparison with other weeds from the Brassicaceae family. However we observed feeding of the cruciferous fleas on shepherd's purse with an average beetle population density of only 0.1-0.6 specimens/plant (Tables 1, 2). This can probably be explained by the fact that the leaf rosette of shepherd's purse lies on the surface of the soil and is always covered with dust; this fact may not attract the insects and prevents them from feeding.

\section{Conclusions}

The host plants as reservoirs for the dominant pests of the oil producing cabbage crops in 2011-2014 were dandelion, caustic buttercup, field mustard, hedge mustard, tansy mustard, yellow rocket and field shepherd's purse. The largest number of species of host plants as reservoirs was found on the roadsides of highways and along the perimeters of fields (six species) and on the meadows (two species). The cruciferous fleas, rape blossom beetles and cruciferous bugs visited such crops as field mustard, hedge mustard and yellow rocket most often. Field shepherd's purse was the least significant among the identified host plants as reservoirs. Only a small amount of the cabbage fleas fed on this crop. This fact can be explained by the small white flowers that do not attract the rape blossom beetle and rose chafer as well as by a ground flat leaf rosette, which is always covered with dust and prevents the fleas and bugs from feeding.

\section{References}

Beleckij E. N. \& Stankevich S. V. (2018). Policiklichnost', sinhronnost' i nelinejnost' populjacionnoj dinamiki nasekomyh i problemy prognozirovanija, Vienna, Premier Publishing s.r.o. Vienna (in Russian).

Beleckij E. N., Stankevich S. V. \& Nemerickaja L. V. (2017). Sovremennye predstavlenija o dinamike populjacij nasekomyh: proshloe, nastojashhee, budushhee. Sinergeticheskij podhod. Vesti HNAU im. V. V. Dokuchaeva. Ser. Fitopatologija i jentomologija, 1-2, 22-33. (in Russian).

Bogdanov-Katkov N. N. (1920). Ogorodnye blohi ili bloshki. Petrograd, Pyataya gosudarstvennaya tipografiya (in Russian). 
Buch W. (1998). Tierische Schädlinge und ihre Antagonisten in Rapskulturen — Arbeiten zu Biologie, Epidemiplogie, natürlicher Regulation und chemischer Bekämpfung in Der 100-jährigen Geschichte der Biologiscen Bundesanstalt für Landß und Forstwirschaft. Mitt. Biol. Bundesanst. Landß und Forstwirt. Berlin. ß Dahnev., 340, 86-106.

Chernij A. M. (2011). Olenka volohata. Karantin i zahist roslin, 6, 5. (in Ukrainian).

Derzhavnij reyestr sortiv roslin pridatnih dlya poshirennya v Ukrayini. (2018). Kiev. (in Ukrainian).

Dobrovolskij B. V. (1959). Rasprostranenie vrednyh nasekomyh. Ochagi i zony naibolshej vredonosnosti. Moscow. Sovetskaya nauka (in Russian).

Golovan L. V., Klymenko I. V. \& Stankevych S. V. et al. (2019). The inheritance of economically valuable features in the intraspecific hybridization of bean (Phaseolus L). Ukrainian Journal of Ecology, 9 (2), 156-169.

Kozhanchikov I. V. (1955). Osobennosti i prichiny geograficheskogo rasprostraneniya vrednyh nasekomyh. Sb. rabot In-ta prikl. zoologii i fitopatologii. Leningrad, ZIN AS USSR, 3, 3-15. (in Russian).

Krishtal O. P. (1959). Komahi-shkidniki silskogospodarskih roslin v umovah Lisostepu ta Polissya Ukrayini. Kiyiv, Vidavnictvo Kiyivskogo universitetu (in Ukrainian).

Prushinski S., Palosh T. \& Mruvchinski M. (1995). Integrirovannaya zashita ozimogo rapsa v Polshe. Zashita rastenij, 6, 16-17. (in Russian).

Puchkov V. G. (1961). Fauna Ukrayini. Shitniki. Vip. 1 Tom 21. Kiyiv, Vidavnictvo AS URSR (in Ukrainian).

Rozova L. V. (2011). Olenka volohata (Epicometis hirta Poda.) v nasadzhennyah plodovih kultur. Karantin i zahist roslin. 8, 12-13 (in Ukrainian).

Stankevich S.V. \& Zabrodina I.V. (2016). Monitoring shkidnikiv silskogospodarskih kultur, Harkiv, FOP Brovin O.V. (in Ukrainian).

Stankevich S.V. (2015). Zmina paradigmi u zahisti olijnih kapustyanih kultur vid hrestocvitih blishok za ostanni 130 rokiv. Visnik HNAU im. V. V. Dokuchayeva. Ser. Fitopatologiya ta entomologiya, 1-2, 156-180. (in Ukrainian).

Stankevich S.V. (2018). Zmina paradigmi u zahisti olijnih kapustyanih kultur vid ripakovogo kvitkoyida za ostanni 140 rokiv. Visnik HNAU im. V.V. Dokuchayeva. Ser. Fitopatologiya ta entomologiya, 1-2, 127-145. (in Ukrainian).

Stankevich S.V., Beleckij E.N. \& Zabrodina I.V. (2019a). Ciklicheski-nelinejnaya dinamika prirodnyh sistem i problemy prognozirovaniya. Vancouver, Accent Graphics Communications \& Publishing. Vancouver. (in Russian).

Stankevych S. V., Yevtushenko M. D. \& Zabrodina I. V. (2019b). V.V. Dokuchaiev Scientific School of Kharkiv National Agrarian University and development agricultural entomology in XIX-XXI centuries. Ukrainian Journal of Ecology, 9 (2), 156-169.

Stankevych S.V., Vasylieva Yu.V. \& Golovan L.V. (2019c). Chronicle of insect pests massive reproduction. Ukrainian Journal of Ecology, 9 (1), $262-$ 274.

Stankevych, S.V., Yevtushenko, M.D. \& Vilna V.V. (2019d). Integrated pest management of flea beetles (Phyllotreta spp.) in spring oilseed rape (Brassica napus L.). Ukrainian Journal of Ecology, 9(3), 198-207.

Stankevych, S. V., Baidyk, H. V. \& Lezhenina, I.P. (2019e). Wandering of mass reproduction of harmful insects within the natural habitat. Ukrainian Journal of Ecology, 9(4), 578-583.

Stankevych S. V., Yevtushenko M. D. \& Vilna V. V. (2019f). Efficiency of chemical protection of spring rape and mustard from rape blossom beetle. Ukrainian Journal of Ecology, 9(4), 584-598

Stankevych, S.V., Biletskyj, Ye.M. \& Zabrodina, I.V. (2020a). Prognostication in plant protection. Review of the past, present and future of nonliner dynamics method. Ukrainian Journal of Ecology, 10(4), 225-234.

Stankevych, S.V., Biletskyj, Ye.M. \& Zabrodina, I.V. (2020b). Cycle populations dynamics of harmful insects. Ukrainian Journal of Ecology, 10(3), 147-161.

Stankevych, S.V., Biletskyj, Ye.M. \& Zabrodina, I.V. (2020c). Prognostication algorithms and predictability ranges of mass re production of harmful insects according to the method of nonliner dynamics. Ukrainian Journal of Ecology, 10(1), 37-42.

Stankevych S.V., Yevtushenko M.D. \& Vilna V.V. (2020d). Dominant pests of spring rape and mustard in the eastern Forest-Steppe of Ukraine and ecologic protection from them: monograph, Kharkiv, Publishing House I.Ivanchenko.

Stankevych, S.V., Biletskyj Ye.M. \& Golovan L.V. (2020e). Polycyclic character, synchronism and nonlinearity of insect population dynamics and prognostication problem: monograph, Kharkiv, PublishingHouse I. Ivanchenko.

Tachvanainen J. O. \& Root R. B. (1972). The influence of vegetational diversity on population ecology of a spezialized herbivore, Phyllotreta cruciferae (Coleoptera: Chrysomelidae). Oecologia, 4, 321-346.

Turenko V. P., Bilyk M. O. \& Zhukova L. V.(2019). Pathogens of spring barley on abiotic factors in the eastern forest - steppe of Ukraine. Ukrainian Journal of Ecology, 9 (2), 179-188.

Vasilev V. P. (1989). Vrediteli selskohozyajstvennyh kultur i lesnyh nasazhdenij. Metody i sredstva borby s vreditelyami, sistemy meropriyatij po zashite rastenij. Kiev, Urozhaj (in Russian).

Yevtushenko M. D., Stankevich S.V. \& Vilna V.V. (2014). Hrestocviti blishki, ripakovij kvitkoyid na ripaku yaromu j girchici u Shidnomu Lisostepu Ukrayini, Harkiv (in Ukrainian).

Yevtushenko M. D., Vilna V. V. \& Stankevich S. V. (2016). Hrestocviti klopi na ripaku yaromu j girchici u Shidnomu Lisostepu Ukrayini, Harkiv, FOP Brovin O.V. (in Ukrainian).

Zhukova L. V., Stankevych, S.V., Turenko, V.P. (2019). Root rots of spring barley, their harmfulness and the basic effective protection measures. Ukrainian Journal of Ecology, 9 (2), 232-238.

\section{Citation:}

Stankevych, S.V., Yevtushenko, M.D., Vilna, V.V., Zabrodina, I.V., Lezhenina, I.P., Baidyk, H.V., Filatov, M.O., Sirous, L.Ya., Yushchuk, D.D., Melenti, V.O., Molchanova, O.A., Matsyura, A.V., Dolya, M.M., Mamchur, R.M., Nemerytska, L.V., Zhuravska, I.A. (2020). Host plants as reservoirs of the main oil-producing cabbage crops pests in the eastern forest-steppe of Ukraine. Ukrainian Journal of Ecology, 106 ), $243-248$.

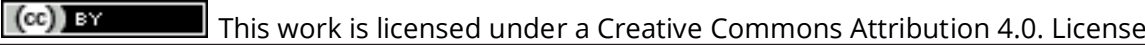

